\title{
Micro-Financing: A Comparative Study of Bangladesh \& Pakistan
}

\author{
Aroosa Khan (Corresponding author) \\ MS Scholar, Institute of Banking \& Finance \\ Bahauddin Zakariya University, Multan, Pakistan \\ ORCID ID: https://orcid.org/0000-0001-8291-6044 \\ E-mail: aroosa54@gmail.com
}

\begin{abstract}
Prof. Dr. Muhammad Shaukat Malik
Dean Faculty Commerce, Law and Business Administration

Director Institute of Banking \& Finance, Bahauddin Zakariya University, Multan, Pakistan

Email: shoukatmalik@bzu.edu.pk
\end{abstract}

Received: July 2, 2020 Accepted: July 13, 2020 Published: July 22, 2020

doi:10.5296/ber.v10i3.17225 URL: https://doi.org/10.5296/ber.v10i3.17225

\begin{abstract}
Purpose: The purpose of the study is to examine impact of micro-financing on poverty alleviation, access to finance and economic growth by comparing Bangladesh and Pakistan.

Design/methodology/approach: Panel data of 56 microfinance institutions drawn by simple random sampling from 2002 to 2013 has been collected from financial statements of microfinance institutions and World Bank. Diagnostic tests, variance inflation factor (VIF) and breusch pagan have been applied to check muticollinearity and heteroscedasticity respectively. Data has been analyzed using fixed effect model as indicated by Hausman test.

Findings: The analysis evidently authenticates that micro-financing has more significant impact on poverty alleviation and economic growth in Pakistan than Bangladesh. At the same time, access to finance in Bangladesh has more noteworthy impact than that of Pakistan.

Originality/value: This study brings to light culmination since beginning of micro-financing on the basis of outcome, experience and comparative regional arrangements helpful for all stakeholders and regulatory authorities in both countries.
\end{abstract}


Keywords: Micro-financing, Microcredit, Poverty alleviation, Access to finance, Economic growth

\section{Introduction}

Pakistan came into existence as independent Muslim state after division of British India in South Asia on 14 August 1947. Pakistan included West Pakistan adjacent to the Arabian Sea, remnant part of India on the east, Afghanistan and Iran on the west and China on the north and East Pakistan bordering the Bay of Bengal in the midst of Myanmar and India. The demand for better sovereignty and hostility between the eastern and western sections of Pakistan flamed Bengali autonomy movement which resulted into forming East Pakistan as separate nation of Bangladesh on 16 December 1971 (separated from West Pakistan). Being Muslim majority area of sub-continent, history, traditions, civilization, populace, living pattern etc. comparatively had insignificant disparity between Bangladesh and Pakistan. Poverty, as a whole, prevailed in this area of southern Asia because of higher birth rate resulting into outsized population, unequal division of wealth and rare usage of technology to explore resources. At present, population of Pakistan is 212 millions having density of 275 people per square $\mathrm{km}$ whereas population of Bangladesh is 161 millions as against density of 1240 people per square $\mathrm{km}$.

Micro-financing is one of most attention grabbing occurrence of recent years having primary progressive agenda worldwide for uplifting poor people. With the passage of time, additional aspects of micro-financing have been identified and realized. Now it has become multi-dimensional tool for eradicating poverty, increasing access to financial services for poor communities, generating employment, empowering women and ultimately contributing to economic growth. The micro-finance sector of Bangladesh is much matured and aged than that of Pakistan, playing appropriate role to lower down higher existence of poverty. The main microcredit plans in Bangladesh are affianced by government concerns like Bangladesh Rural Development Board (BRDB), Pallil Karma Sahayak Foundation (PKSF), Grameen Bank (GB) and non-government groups such as Bangladesh Rural Advancement Committee (BRAC), Palli Daridro Bimochon Foundation (PDBF), and Association for social Advancement (ASA). The Grameen Bank is a winning model of microcredit programmes beyond all likewise functionaries in Bangladesh. The organization was established by Dr. Muhammed Yunus in 1976 as a result of action study assignment in "Jobra village" of Chittagong district. In 1983 it was changed into a proper bank under a particular law approved for its formation. It is owned by the poor customers of the bank who are women for the most part. Presently $94 \%$ of the entire equity of the organization is owned by customers of Grameen bank and residual 6 percent is kept by the government. The Grameen Bank perception of microcredit has been followed in more than 60 countries around the world.

Govt. of Pakistan, however, realizing the necessity and significance of microfinance, initiated microfinance sector development program (MSDP) in the year 2000 with the key objective to make available the financial services to the poor on maintenance basis. To further strengthen this program, the first microfinance bank-Khushhali Bank (KB), was approved to be established by Govt. of Pakistan on 12th August 2000. A separate regulatory framework 
through an ordinance was promulgated in 2001 particularly for microfinance sector. Similarly MFIs in Pakistan are exploring new avenues in an efficient way under the supervision and guidelines of regulatory authorities. During recent years, micro-insurance regulations were initiated and regulated by the Securities and Exchange Commission of Pakistan (SECP) to systemize the framework and streamline the micro-insurance operations in Pakistan. It continued to attract the foreign inflow of funds both in terms of equity and debt causing expansion for microfinance industry. The FINCA International got hold of Kashf Microfinance Bank and ECO Trade and Development Bank afforded huge lending to NRSP to promote added development in this sector.

Adequate studies have been carried out on the subject of micro-financing but examined only its specific aspects such as poverty alleviation (Sivachithappa, 2013; Paul, 2014), access to finance (Weber \& Musshoff, 2013), economic growth (Ahmeti, 2014; Ademola e \& Arogundade, 2014) etc in different regions of the world. Overall study of micro-financing comparing Pakistan with specific countries like Bangladesh together in the field of poverty alleviation, access to financial services to poor communities, and economic growth, almost not found. Various authors have examined comparative studies separately of particular subjects among different regions but micro financing comparison of Pakistan and Bangladesh in all perspectives discussed above not evidenced. It is a comparative study of micro financing taking into account two countries having similar background even one and the same nation since 1947 to 1971 . After separation, their priorities changed due to division of resources and environmental belongings. This study will look at:

- The legendary background on the topic of micro-financing and its extent similarity in Bangladesh and Pakistan.

- Overall contribution of micro-financing in Pakistan and Bangladesh, especially in the field of poverty alleviation, access to financial services to poor communities and economic growth.

\section{Literature Review}

\subsection{What is Meant by Micro financing?}

Micro-financing deals with financial assistance like credits, insurance, savings etc, to deprived and needy poor people having no collateral to offer as securities against even small amount of loans. Such borrowers are not entertained by formal financial institutions because of non-remunerative and petty bulk transactions, expensive operational cost and higher risks of default. Otero (1999) defined microfinance as availability or access of financial stipulation to underprivileged freelance group of people having nominal earning. Ledgerwood (2000) highlights availability of extended financial services like disbursement services and insurance to poor community. There exist variance in desires by poor households and for this reason, microfinance institutions often use non-conventional line of action such as group lending or entertainment of other varieties of securities generally unacceptable by the formal financial organizations. Okiocredit (2005) explains that micro-financing is not totally about microcredit; it is only a component of microfinance like other constituents like availability of financial services to poor who are non-credit based like payment services, savings, insurance 
and pension.

\subsection{Impacts of Micro-financing}

This section entails major Impacts of micro-financing on poverty alleviation, improvement in access to finance and economic growth.

\subsubsection{Poverty Alleviation}

The meaning of poverty as affirmed by World Bank's (1980) "A state of life beneath any reasonable definition of human decency as a result of undernourishment, illiteracy and diseases". Social troubles and rise of various illicit activities are mostly resultants of poverty. Its alleviation aims to improve the quality of life for those people currently living in worse conditions. Poverty is identified by non-availability of basic essentials and supplies (food, ration etc.) to a person or community for a least standard of living. Poverty is a big obstacle in achieving most important objectives of economic development.

\subsubsection{Poverty Trends}

The percentage of the populace existing beneath the national poverty line is termed as poverty headcount ratio at national poverty lines. It is the proportion of population living lower than state poverty line. Keeping in check the same values, it is declared that poverty is declining over time in both countries. But still more people are living below the national poverty line in Bangladesh than in Pakistan.

\subsubsection{How Micro-financing Reduces Poverty?}

Poverty is sadistic cycle characterized by illiteracy, illness and vulnerability. Microfinance institutions provide micro credit to poor's that creates self employments, savings, self sufficiency, and uplift standard of living thus leads to alleviation of poverty.

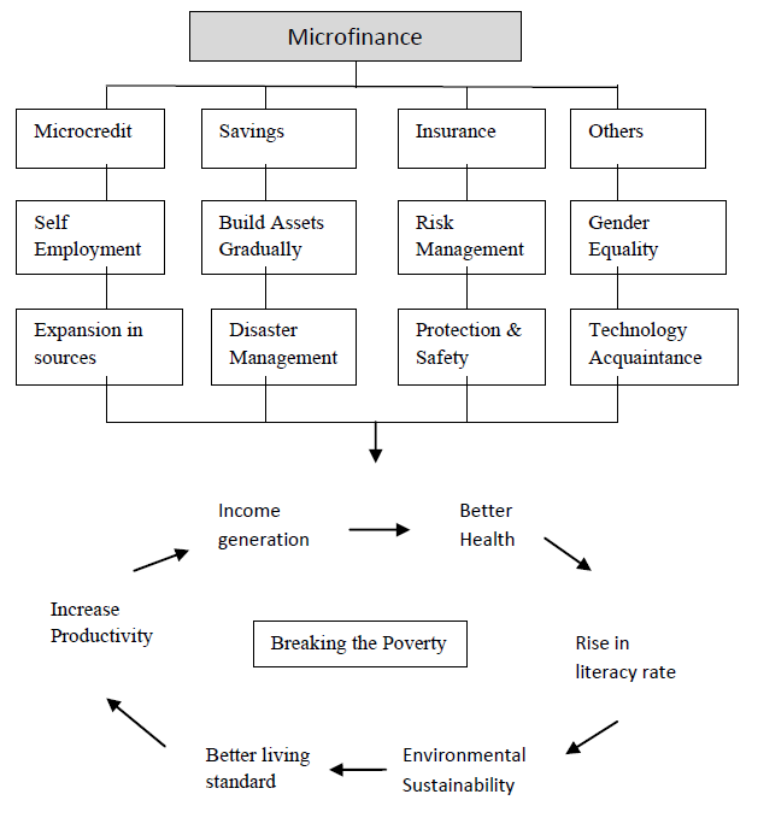

Figure 1. How Microfinance reduces poverty? 
Major part of microloans is shared by women that empower them to ensure gender equality. Health conditions, access to education and environmental sustainability are improved due to income generation causing alleviation of poverty. It is notable that previous models like of Khan (2010) usually elaborated elimination of poverty by mean of microcredit while the model sketched above expresses wide ranging impact about poverty alleviation by mean of other financial services in addition to microloans. Microfinance is the credible way out to lessen the poverty besides the others authoritative techniques. The unprivileged people have recognized micro finances as a tool to come up to the education, better health and accommodation conveniences as well as others necessary requirements (Murdoch and Haley 2002).

\subsubsection{Relationship between Microfinance and Poverty; Empirical Evidence}

Microfinance encourages poor people to diversify and boost income sources, the essential corridor towards basic needs. The study in Lombok, Indonesia, exhumed that $93 \%$ of microfinance beneficiaries ate meals thrice a day, compared with $51 \%$ of non-recipients (Panjaitan-Drioadisuryo et al., 1999). A survey in Bangladesh on MFI customers proved that smaller number of clients experienced severe malnutrition (relative to the organize group), and, more notably, the level of severe malnutrition turned down as the length of membership enhanced (Chowdhury and Bhuiya, 2001). Micro financing takes share in directly reducing excessive poverty coupled with improving the income of poor people. In China (PRC), microfinance agenda facilitated uplifting of 150 million people from poverty since 1990 (UNHDR, 2005). By making use of Poverty Assessment Tool (PAT), Simanowitz (2003), searched out that three-fourths customers of the microfinance institutions (MFIs) fetched significant economic improvements and half the clients went out of poverty in India. The survey of World Bank in 1998 exhumed that the poorest $48 \%$ of Bangladeshi families with admittance to microcredit from Grameen Bank jumped above the poverty line. Furthermore, in Ghana, MkNelly and Dunford (1998) found that customers improved their income by $\$ 36$, compared with $\$ 18$ for no clients. Users of microfinance, in general, shifted from uneven, low-paid daily work to permanent jobs in India (Simanowitz, 2003) and Bangladesh (Zaman, 2000). Filipino family units showed rise in earnings, expenditure, and assets (Chowdhury, 2004).

Rastogi (2014) conducted relative study between ASA and Bandhan microfinance institution of Bangladesh and India likewise and exposed that micro financing developed the economy by eliminating poverty. At one end of the thought, it is prevalent that microfinance is helpful and valuable means for poverty lessening (e.g. Hossain, 1988; Khandker, 1998; Barnes, 2001; McKernan, 2002; Dunn, 2002; Snodgrass \& Sebstad, 2002; Littlefield, Murduch \& Hashemi, 2003; Bernasek, 2003; Alam \& Miyagi, 2004; Goldberg, 2005; Khandker, 2005; Sachs, 2005; Haseen, 2006; Miller \& Martinez, 2006; Rabbani et al., 2006; Stephens \& Tazi, 2006; Mahjabeen, 2008; Banerjee et al., 2009; Imai et al., 2010; Imai \& Azam, 2012).

\subsection{Access to Finance}

Access to finance is the intent of unbanked persons or enterprises to acquire financial services, including credit, deposit, remittances and different risk management services. There is broad 
consensus that access to bank account being first step, not the end leading to gateway for other financial products such as savings, credit and insurance, can help people better manage their life. Access to financial services in developing countries has improved in recent years because of global initiatives. Micro-financing has also played role in expanding access but still two billion people worldwide lack access to regulated financial services. Numerous indicators of access are:

- Tradition of using banks as primary financial institutions (public \& private)

- Making use of mostly non-bank financial institutions

- Ability to reach the financial institution they use by foot (word bank, 2004).

\subsubsection{Comparative Financial Penetration}

There is substantial disproportion in financial inclusion indicators across Bangladesh and Pakistan as matched by the Global Financial Inclusion database. Bangladesh has penetration levels of $40 \%$ whereas Pakistan has comparatively lesser financial access with about $10 \%$ of the populace maintaining account in formal financial institutions. The private sharing in the banking sector of Bangladesh and Pakistan is ahead of $60 \%$. Institutional model in the microfinance area alter significantly as experimentation occurring more in Bangladesh. Both countries have implemented a variety of diverse policies and authoritarian structure for the financial sector. The most distinguished strategy preference has been that of state-rights vis-à-vis liberalization. Pakistan's banking sector have been provided balanced regulatory environment hence ranked among the foremost countries of South Asia to launch set of laws in 2001 for MFBs.

\subsubsection{How Micro Finance Improves Access to Finance?}

It is believed that micro finance is a helpful mean for improving reach to financial services. Billions of households worldwide have no way in to financial services. MFIs, as newly sub section of financial institutions, tender services to those who are neglected by conventional financial institutions or to unbanked people. As a result, a lot number of people get benefit of banking services through microfinance institutions at door step. Moreover, attaining access to financial services is a significant pace in involving the poor to an extensive economic life. MFIs have a preference to bank in remote rural areas where poor people are engaged to share for their own welfare whereas conventional banks expand their business in commercial and industrial hubs with intension to earn more. The figure below shows how MF develops access to finance. 


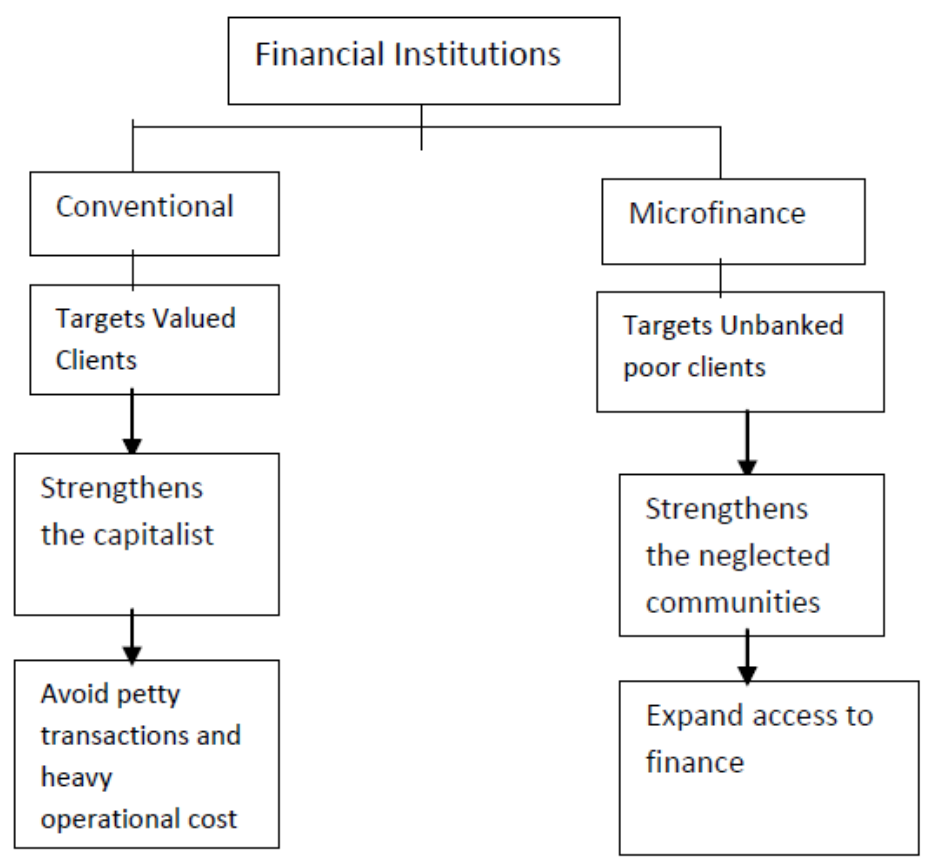

Figure 2. How Micro finance improves access to finance?

Access to financial services for neglected people may accomplish mission of poverty alleviation.

\subsubsection{Relationship between Micro-financing and Access to finance; Empirical Evidence}

The Microfinance industry may contribute a vital and significant role in the wide-ranging economic field. They have the capacity to create innovation and employment which can elevate the economy to a higher stage. It provides extensive collection of monetary and economic services together with credit products in addition to micro-credits, savings, remittances and insurance. This industry can convert huge part of population earning lower income towards formal banking system as compared to other segments in the financial industry. Sharing its enthusiasm because of branchless banking and outreach in remote vicinity, the industry may be a valuable medium for expanding access to financial services across the orbit of operation. Different segments like domestic industry of hand made products, low cost housing projects and inputs for poor farmers are foremost source in availing microcredit and insurance facilities extended by the microfinance industry as compared to additional group of performers in the financial sectors.

A number of microfinance institutions are functioning and operating for resolving the problems of poor peoples who are ignorant and ill informed, having no access to finances (Befekadu, 2007). As per another research by Coleman (2004), it transpires that wealthy people have larger access to micro finance than poorer. Sichanthongthip (2004) study proved that micro finance has positive impact on member`s enhanced periodical income level after his access to finance. Qureshi et al (2012) has also opined that micro finance positively associated with access to micro finance. 


\subsection{Economic Growth}

Economic growth is a long-run process that occurs as an economy's potential output augmentation. Micro-financing reduces poverty whereas Growth doesn't necessarily reduce poverty but without economic growth it is very difficult to make any meaningful and sustained reduction in poverty. This is especially important in developing economies as it reduces unemployment and enables improvement in Living Standards subject to appropriate management. The economic activities are intense and fruitful in urban and developed areas as compared to rural and remote areas where poorer people are separated by distance (remote vicinity). Bringing poor populace in the developmental corridor is mandatory to grasp fair economic growth.

\subsubsection{Trends of Economic Growth}

Before separation, tendency of economic growth was identical in both east and west parts but after partition particularly since 1975, economic growth of Pakistan was being evaluated better than Bangladesh. GDP Growth Rate in Bangladesh averaged 5.66 percent from 1994 until now, reaching an all time high of 6.63 percent in 2006 and a record low of 4.08 percent in 1994. At present, Bangladesh has performed reasonably well in terms of economic growth. Real GDP growth rate of Bangladesh since 2010 has been reported equal to or above $6 \%$ due to development of microcredit and garment industry. On the other hand Growth in Pakistan has adversely affected because of energy crisis and security issues. Pakistan and Bangladesh are developing economies so only GDP \% is not precise comparison for economic growth. Pakistan's GDP as of 2013 was \$232 Billion as compared to Bangladesh of \$150.

\subsubsection{How Micro Finance Contributes toward Economic Growth?}

As microfinance enhances access to financial services that improves the aptitude of customers to markets, that contributes drive to sustain values of products and services, makes possible risk pooling, and allows value storage, thus keeping up economic growth and on the whole constancy of the system.

\subsubsection{Relationship between Micro Financing and Economic Growth; Empirical Evidence}

Microfinance is a latest fundamental approach to financing progress that limelight primarily on the poor people. It was resultant of the non-availability of approach to financial services being faced by abundance of people across the world, who are not entertained by the formal financial system (Helms 2006).

There is ample academic, hypothetical and experimental inscription that endorses a confirmatory result of the financial quarter (i.e. banking, debt and equity markets,) on economic development at the level of company, industry and nation [King \& Levine (1993), Levine \& Zervos (1998), La Porta et al (1998), Rajan \& Zingales (1998), Beck \& Levine (2004)]. On the other hand, progressive researchers believe that what in reality reckoning is the access to finance [Ravallion (2001), Beck et al (2007) and others].To make sure economic sustainable growth better access to finance reduces in size the income disproportion and subsequently poor households, in undoubted majority, get rid of poverty; resultantly 
sustainability of economic growth is made certain. It is essential for developed countries to have access to formal financial services for establishing effective market-based financial system. Nevertheless poor people in developing countries necessitate access to financial services than proper bank credits as conventional bankers time and again prohibit them as unappealing clients because of far above the ground risk and inadequate property for collateral (Beck et al 2008). The availability of microfinance facilities in the shape of small loans free of tangible (without collateral) securities, savings and insurance has thus converted as a very important choice for poor people's positive operations in establishing their own business and getting standard of living, much better.

Without financing, the economic growth cannot be achieved (Hermes and Meesters 2011 and Roodman 2012). Similarly argued by Schumpeter (1934) that financial intermediation stimulates development by making out creative investments, microfinance maintains fruitful small scale enterprises for the poor households through backing of investment in substantial capital (Okurut et al. 2005). Obasi et al (2014) discussed the impact of microfinance loans on Nigerian economy, by ascertaining small lending to undersized, small and medium business enterprise that finally influence the economy of state and realized that microcredit assistance is essential for economic growth of nations.

It has been proved through recent publication of five randomized control trials (RCTs) that microfinance positively affects microeconomic activities (Crépon et al. 2011, Attanasio et al. 2011, Augsburg et al. 2012, Angelucci et al. 2013 and Duflo et al. 2013). A few lately published articles review performance of microfinance with regard to macroeconomic activity at macro level. Especially, Buera et al. (2012) and Ahlin and Jiang (2008) suggest two hypothetical model to observe the prospective of MF to produce a steady course of development (the former) and its possibility to generate a recirculative outcome on the economy in a country taken as a whole (the latter). Imai et al. (2012) examined the impact of MF on poverty intensity nationwide. Lastly, Ahlin et al. (2011) and Hermes and Meesters (2011) examine the correlation linking macroeconomic situations and the act of microfinance organizations.

The performance of microfinance providers has no linkage with the GDP growth rate, as affirmed by a study of Woolley (2008). The performance of MFPs has been rated sound in terms of operational self-reliance, profitability, and portfolio fineness yet in economic slump and period of meager economic growth. This resultant strengthens the viewpoint that microfinance is helpful in lessening poverty yet in situation of low GDP growth. It shares to strengthen economy by alleviating poverty, generating self employment and providing excess to financial services.

\section{Model and Hypothesis}




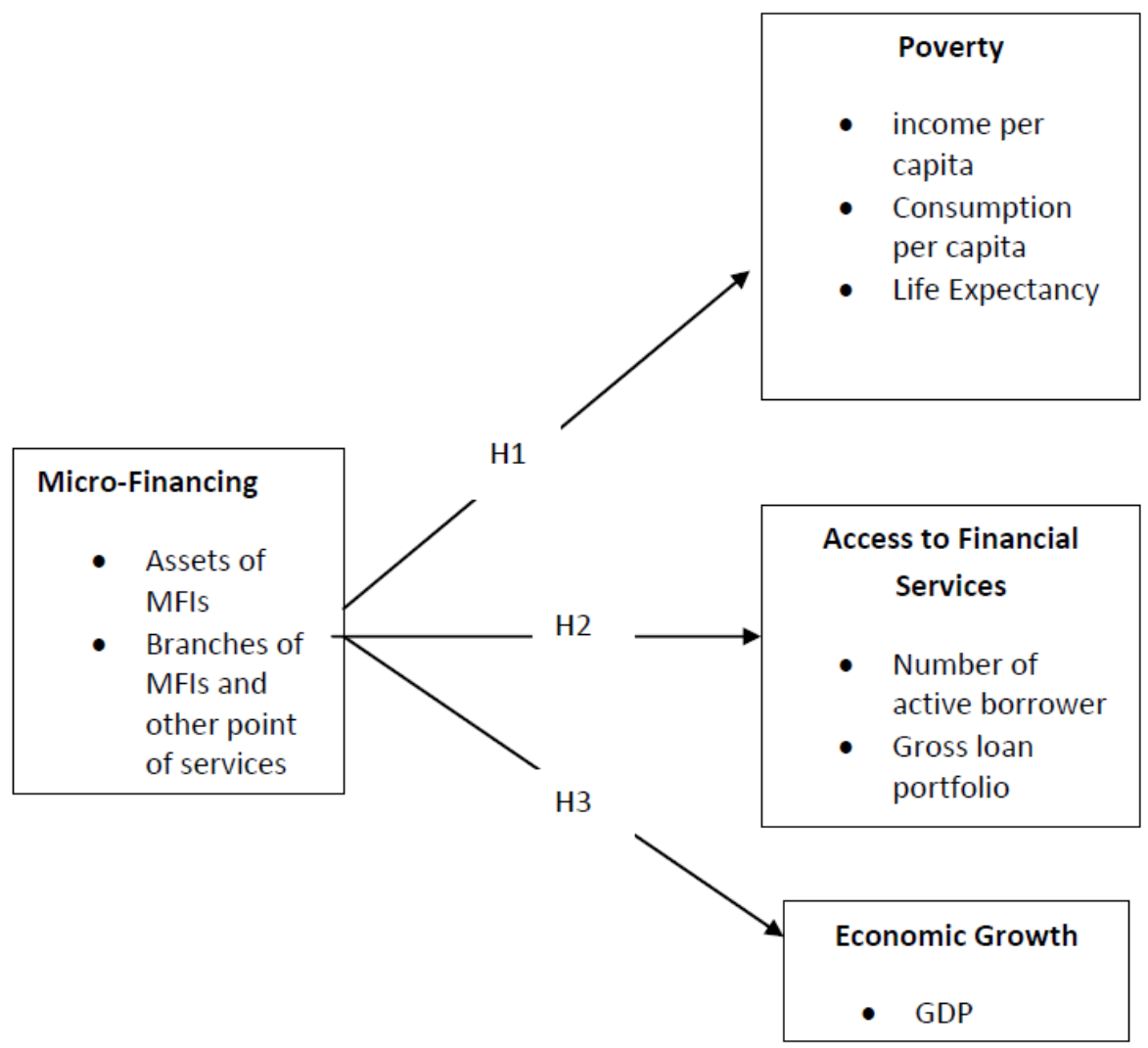

Figure 3. Hypothesized Research Model

\section{$\mathrm{H}_{1}$ : Impact of micro-financing on poverty is better in Pakistan than Bangladesh.}

$\mathrm{H}_{1 \mathrm{a}}$ : Impact of micro-financing (Assets of MFIs and Branches of MFIs and other point of services) on poverty (income per capita) is better in Pakistan than Bangladesh.

$\mathrm{H}_{1 \mathrm{~b}}$ : Impact of micro-financing (Assets of MFIs and Branches of MFIs and other point of services) on poverty (consumption per capita) is better in Pakistan than Bangladesh.

$\mathrm{H}_{1 \mathrm{c}}$ : Impact of micro-financing (Assets of MFIs and Branches of MFIs and other point of services) on poverty (life expectancy) is better in Pakistan than Bangladesh.

$\mathrm{H}_{2}$ : There is significant impact of micro financing on access to financial services in Bangladesh than Pakistan.

$\mathrm{H}_{2 \mathrm{a}}$ : There is significant impact of micro-financing (Assets of MFIs and Branches of MFIs and other point of services) on access to financial services (Number of active borrower) in Bangladesh than Pakistan.

$\mathrm{H}_{2 \mathrm{~b}}$ : There is significant impact of micro-financing (Assets of MFIs and Branches of MFIs and other point of services) on access to financial services (Gross loan portfolio) in Bangladesh than Pakistan.

$\mathrm{H}_{3}$ : Microfinance contributes more toward economic growth in Pakistan than 


\section{Bangladesh.}

\section{Research Methodology}

Methodology is the most vital and significant part of research study that is used to verify the conceptual framework and leads to realization of research objectives subject to its perfect compilation. The panel data of 56 sample microfinance banks, NGO's and NBFI's operating in Pakistan and Bangladesh drawn from population by random sampling techniques, from 2002 to 2013 has been collected from secondary sources i.e. financial statements of MFIs, World bank.

Following regression equations are developed:

$$
\begin{aligned}
& \mathbf{P}=\boldsymbol{\alpha}+\boldsymbol{\beta}_{\mathbf{0}} \mathbf{M F}+\boldsymbol{\varepsilon} \\
& \mathrm{IPC}=\alpha+\beta_{0} \mathrm{~A}+\beta_{0} \mathrm{~B}+\varepsilon \\
& \mathrm{CPC}=\alpha+\beta_{0} \mathrm{~A}+\beta_{0} \mathrm{~B}+\varepsilon \\
& \mathrm{LE}=\alpha+\beta_{0} \mathrm{~A}+\beta_{0} \mathrm{~B}+\varepsilon \\
& \mathrm{AFS}=\boldsymbol{\alpha}+\boldsymbol{\beta}_{0} \mathbf{M F}+\boldsymbol{\varepsilon} \\
& \mathrm{NDA}=\alpha+\beta_{0} \mathrm{~A}+\beta_{0} \mathrm{~B}+\varepsilon \\
& \mathrm{GLP}=\alpha+\beta_{0} \mathrm{~A}+\beta_{0} \mathrm{~B}+\varepsilon \\
& \mathbf{E G}=\boldsymbol{\alpha}+\boldsymbol{\beta}_{0} \mathbf{M F}+\boldsymbol{\varepsilon} \\
& \mathrm{GDP}=\alpha+\beta 0 \mathrm{~A}+\beta_{0} \mathrm{~B}+\varepsilon
\end{aligned}
$$

Where $\alpha=$ constant, $\beta_{0}=$ coefficient of respective variable, $\varepsilon=$ error term, $\mathrm{P}=$ Poverty, $\mathrm{MF}=$ Micro-financing, $\mathrm{A}=$ Assets, $\mathrm{B}=$ Branches/offices, $\mathrm{IPC}=$ Income per capita, $\mathrm{CPC}=$ Consumption per capita, LE $=$ Life Expectancy, AFS= Access to financial services, NDA= Number of deposit accounts, GLP= Gross loan portfolio, EG= Economic growth, GDP= Gross domestic product.

Data has been analyzed by Stata version 12, statistical packages. Diagnostic tests, variance inflation factor (VIF) and breusch pagan have been applied to check muticollinearity and heteroscedasticity respectively. For panel data analysis three basic models are Pooled OLS Regression Model, Random effects Model and Fixed Effects Model. The appropriate model has been selected by using Housman test.

Validity and reliability, two important concepts, also kept in this study as the appropriate methodology is employed and the data has been collected from reliable secondary sources

\section{Results and Discussion}

Diagnostic tests, variance inflation factor (VIF) and breusch pagan shows there are no muticollinearity and heteroscedasticity problems.

\section{Relationship between Micro financing and Income per capita}

H1a: Impact of micro-financing (Assets of MFIs and Branches of MFIs and other point of services) on poverty (income per capita) is better in Pakistan than Bangladesh. 
Table 1. Fixed Effect Regression of Microfinance and Income per capita

\begin{tabular}{|l|l|l|l|l|l|l|}
\hline \multirow{2}{*}{} & \multicolumn{3}{|l|}{ Pakistan } & \multicolumn{3}{l|}{ Bangladesh } \\
\cline { 2 - 7 } & & Assets & Offices & & Assets & Offices \\
\hline Prob > F & 0.0000 & & & 0.0000 & & \\
\hline R-sq (within) & 0.2252 & & & 0.1936 & & \\
\hline $\mathrm{T}$ & & 3.80 & 4.70 & & 5.29 & 2.99 \\
\hline $\mathrm{P}>|\mathrm{t}|$ & & 0.000 & 0.000 & & 0.000 & 0.003 \\
\hline
\end{tabular}

Above table depicts that

- The model is robust as the value of test (F) is less than 0.05 .

- Two tail $\mathrm{p}$-values shows that microfinance (Assets and offices other points of services) has significant influence on income per capita as the values are less than 0.05 .

- $\quad \mathrm{t}$ - Values also confirm that microfinance (Assets and offices other points of services) has significant influence on income per capita and are relevant variable as the values are more than 1.96 .

- R square or coefficient of determination describes percentage change or variation in dependent variable explained by the model. R square (within) shows that $22.52 \%$ and $19.36 \%$ change in income per capita is caused by Microfinance in Pakistan and Bangladesh respectively.

The relationship between microfinance and income per capita is significant but the degree of variation varies in both countries upon which it is concluded that the impact of micro financing on income per capita is better in Pakistan than Bangladesh. Thus hypothesis H1a is accepted.

\section{Relationship between Micro financing and Consumption per capita}

$\mathbf{H}_{\mathbf{1 b}}$ : Impact of micro-financing (Assets of MFIs and Branches of MFIs and other point of services) on poverty (consumption per capita) is better in Pakistan than Bangladesh.

Table 2. Fixed Effect Regression of Microfinance and Consumption per capita

\begin{tabular}{|l|l|l|l|l|l|l|}
\hline \multirow{2}{*}{} & \multicolumn{2}{|l|}{ Pakistan } & \multicolumn{2}{l|}{ Bangladesh } \\
\cline { 2 - 7 } & & Assets & Offices & & Assets & Offices \\
\hline Prob > F & 0.0000 & & & 0.0000 & & \\
\hline R-sq (within) & 0.2238 & & & 0.1970 & & \\
\hline $\mathrm{T}$ & & 3.14 & 5.23 & & 4.96 & 3.48 \\
\hline $\mathrm{P}>|\mathrm{t}|$ & & 0.002 & 0.000 & & 0.000 & 0.001 \\
\hline
\end{tabular}

Above table reflects that

- The model is robust as the value of test $(\mathrm{F})$ is less than 0.05 .

- Two tail p -values and t- Values shows that microfinance (Assets and offices other points of services) has significant influence on consumption per capita

- R square (within) shows that $22.38 \%$ and $19.70 \%$ variation in consumption per capita is explained by Microfinance in Pakistan and Bangladesh respectively. 
The relationship between microfinance and consumption per capita is significant but the degree of variation varies in both countries upon which it is concluded that the impact of micro financing on consumption per capita is better in Pakistan than Bangladesh. Thus hypothesis H1b is accepted.

\section{Relationship between Micro financing and Life Expectancy}

$\mathbf{H}_{1 \mathbf{c}}$ : Impact of micro-financing (Assets of MFIs and Branches of MFIs and other point of services) on poverty (life expectancy) is better in Pakistan than Bangladesh.

Table 3. Fixed Effect Regression of Microfinance and Life Expectancy

\begin{tabular}{|l|l|l|l|l|l|l|}
\hline \multirow{2}{*}{} & \multicolumn{3}{|l|}{ Pakistan } & \multicolumn{3}{l|}{ Bangladesh } \\
\cline { 2 - 7 } & & Assets & Offices & & Assets & Offices \\
\hline Prob > F & 0.0000 & & & 0.0000 & & \\
\hline R-sq (within) & 0.2319 & & & 0.2000 & & \\
\hline $\mathrm{T}$ & & 4.10 & 4.57 & & 5.22 & 3.27 \\
\hline $\mathrm{P}>|\mathrm{t}|$ & & 0.000 & 0.000 & & 0.000 & 0.001 \\
\hline
\end{tabular}

Above table demonstrates that

- The model is robust as the value of test $(\mathrm{F})$ is less than 0.05 .

- Two tail $\mathrm{p}$-values and t- Values shows that microfinance (Assets and offices other points of services) has significant influence life expectancy.

- R square (within) shows that $23.19 \%$ and $20 \%$ variation in life expectancy is explained by Microfinance in Pakistan and Bangladesh respectively. In other words, due to micro-financing life expectancy is improved by $23.9 \%$ and $20 \%$ in Pakistan and Bangladesh respectively.

The relationship between microfinance and life expectancy is significant but the degree of variation varies in both countries upon which it is concluded that the impact of micro financing on life expectancy is better in Pakistan than Bangladesh. Thus hypothesis H1c is accepted.

\section{Relationship between Micro financing and Poverty}

$\mathbf{H}_{\mathbf{1}}$ : Impact of micro-financing on poverty is better in Pakistan than Bangladesh.

The relationship between micro-financing and poverty has been evaluated on the basis of above three hypotheses which measures the impact of micro-financing on the three chosen measures of poverty i.e. income per capita, consumption per capita and life expectancy.

As the relationship between micro-financing and different measures of poverty is positively significant but better influence is in Pakistan than Bangladesh. So it is concluded that overall the better impact of micro-financing on poverty is in Pakistan than Bangladesh. Thus, leads to acceptance of hypothesis $\mathrm{H} 1$.

\section{Relationship between Micro financing and Number of active borrowers}

$\mathbf{H}_{2 \mathbf{a}}$ : There is significant impact of micro-financing (Assets of MFIs and Branches of MFIs and 
other point of services) on access to financial services (Number of active borrower) in Bangladesh than Pakistan.

Table 4. Fixed Effect Regression of Microfinance and Number of Active Borrower

\begin{tabular}{|l|l|l|l|l|l|l|}
\hline \multirow{2}{*}{} & \multicolumn{3}{|l|}{ Pakistan } & \multicolumn{3}{l|}{ Bangladesh } \\
\cline { 2 - 7 } & & Assets & Offices & & Assets & Offices \\
\hline Prob > F & 0.0000 & & & 0.0000 & & \\
\hline R-sq (within) & 0.5147 & & & 0.5748 & & \\
\hline $\mathrm{T}$ & & 5.63 & 9.99 & & 10.85 & 8.93 \\
\hline $\mathrm{P}>|\mathrm{t}|$ & & 0.000 & 0.000 & & 0.000 & 0.000 \\
\hline
\end{tabular}

Above table makes obvious that:

- The model is robust as the value of test $(\mathrm{F})$ is less than 0.05 .

- Two tail $\mathrm{p}$-values and $\mathrm{t}$ - Values shows that microfinance (Assets and offices other points of services) has significant influence on number of active borrower.

- $\mathrm{R}$ square (within) shows that $51.47 \%$ and $57.48 \%$ variation in number of active borrower is explained by Microfinance in Pakistan and Bangladesh respectively. In other words, due to micro-financing number of active borrower is improved by $51.47 \%$ and $57.48 \%$ in Pakistan and Bangladesh respectively. The more people have access to financial services in Bangladesh than Pakistan.

The relationship between microfinance and number of active borrower is significant but the degree of variation varies in both countries upon which it is concluded that the impact of micro financing on number of active borrower is better in Bangladesh than Pakistan. Thus hypothesis $\mathrm{H} 2 \mathrm{a}$ is accepted.

\section{Relationship between Micro financing and Gross loan portfolio}

$\mathbf{H}_{\mathbf{2 b}}$ : There is significant impact of micro-financing (Assets of MFIs and Branches of MFIs and other point of services) on access to financial services (Gross loan portfolio) in Bangladesh than Pakistan.

Table 5. Fixed Effect Regression of Microfinance and Gross Loan Portfolio

\begin{tabular}{|l|l|l|l|l|l|l|}
\hline \multirow{2}{*}{} & \multicolumn{2}{|l|}{ Pakistan } & \multicolumn{3}{l|}{ Bangladesh } \\
\cline { 2 - 7 } & & Assets & Offices & & Assets & Offices \\
\hline Prob > F & 0.0000 & & & 0.0000 & & \\
\hline R-sq (within) & 0.8755 & & & 0.9113 & & \\
\hline $\mathrm{T}$ & & 34.28 & 1.59 & & 45.08 & 3.87 \\
\hline $\mathrm{P}>|\mathrm{t}|$ & & 0.000 & 0.113 & & 0.000 & 0.000 \\
\hline
\end{tabular}

Above table demonstrates that

- The model is robust as the value of test $(\mathrm{F})$ is less than 0.05 .

- Two tail $\mathrm{p}$-values and $\mathrm{t}$ - Values shows that microfinance (Assets and offices other points of services) has significant influence on gross loan portfolio except one 
dimension of micro-financing, other points of services in case of Pakistan having $\mathrm{p}$-value greater than 0.05 and t-value less than 1.96 .

- $\mathrm{R}$ square (within) shows that $87.55 \%$ and $91.13 \%$ variation in gross loan portfolio is explained by Microfinance in Pakistan and Bangladesh respectively.

The relationship between microfinance (Assets and offices other points of services) and in gross loan portfolio is significant in case of Bangladesh while in case of Pakistan only one dimension of micro-financing has significant influence on gross loan portfolio. The degree of variation differs in both countries upon which it is concluded that the impact of micro financing on gross loan portfolio is more significant and better in Bangladesh than Pakistan. Thus hypothesis $\mathrm{H} 2 \mathrm{~b}$ is accepted.

\section{Relationship between Micro financing and Access to financial services}

$\mathbf{H}_{2}$ : There is significant impact of micro financing on access to financial services in Bangladesh than Pakistan.

The relationship between micro financing and Access to financial services has been concluded on the basis of above two hypotheses which evaluate the impact of micro-financing on the two chosen measures of access to financial services i.e. number of active borrower and gross loan portfolio.

As the relationship between micro-financing and two dimensions of access to financial services is more significant and better in Bangladesh than Pakistan. So it is concluded that overall the greater impact of micro-financing on access to financial services exist in Bangladesh than Pakistan. Thus, leads to acceptance of hypothesis H2.

\section{Relationship between Micro financing and Economic growth}

$\mathbf{H}_{3}$ : Microfinance contributes more toward economic growth in Pakistan than Bangladesh.

Table 6. Fixed Effect Regression of Microfinance and Economic growth

\begin{tabular}{|l|l|l|l|l|l|l|}
\hline \multirow{2}{*}{} & \multicolumn{3}{|l|}{ Pakistan } & \multicolumn{3}{l|}{ Bangladesh } \\
\cline { 2 - 7 } & & Assets & Offices & & Assets & Offices \\
\hline Prob > F & 0.0000 & & & 0.0000 & & \\
\hline R-sq (within) & 0.2307 & & & 0.1960 & & \\
\hline T & & 3.75 & 4.86 & & 5.27 & 3.08 \\
\hline P $>|t|$ & & 0.000 & 0.000 & & 0.000 & 0.002 \\
\hline
\end{tabular}

Above table reveals that

- The model is robust as the value of test $(\mathrm{F})$ is less than 0.05 .

- Two tail $\mathrm{p}$-values and $\mathrm{t}$ - Values shows that microfinance (Assets and offices other points of services) has significant influence on economic growth.

- $\mathrm{R}$ square (within) shows that $23.07 \%$ and $19.60 \%$ variation in economic growth is explained by Microfinance in Pakistan and Bangladesh respectively.

The relationship between microfinance and economic growth is significant but the degree of 
variation differs in both countries upon which it is concluded that the impact of micro financing on economic growth is better in Pakistan than Bangladesh. Thus hypothesis H3 is accepted.

\section{Conclusion}

This study focuses on background of micro-financing and its realistic approach with special reference to its existence and contribution in Pakistan and Bangladesh, particularly in the field of poverty alleviation, access to financial services and economic growth in addition to achievements of MFIs by comparing their financial performance and innovation. Attempt has been made to empirically investigate state and significance of micro-financing in both selected countries by analysing secondary data from 56 MFIs.

The main purpose of MFIs is said to alleviate poverty but higher rate of return on credit to poor people is a question mark and point of condemnation by forecasters. Despite all negatives, the significant positive impact of micro-financing on poverty is found and also supported by literature (Mosley, 2001; Ayuub 2013; Khandker \& Samad, 2013; Miled \& Rejeb, 2015; Samer et al, 2015). The comparative analysis of Pakistan and Bangladesh on the issue shows that noteworthy impact exists in Pakistan than Bangladesh. Though both countries have more or less alike historic background, under-developed and prejudiced by developed nations of world in terms of franks theory of dependency yet exporting raw material against costly finished goods due to lack of enough infrastructure and technology. MFIs started their operations at grassroots to accommodate those who are neglected by conventional banks because of their inability to provide collateral as security against credit. The Gremeen bank proved that micro loans allowed to poor in groups help elevate their standard of living with wonderful results of recovery percentage. The trends of facts and figure as poverty headcount ratio show that more people are living below national poverty line in Bangladesh than Pakistan. Due to increased poverty in Bangladesh, the impact of micro-financing on poverty lessening is significant but not as much as Pakistan.

One of challenge and aim of financial system is access to financial services. MFIs serve as the added mode to increase access to financial services. The momentous impact of micro-financing has been found on access to financial services in both countries also corroborated by literature (Shankar, 2013; Zulfiqa, 2013). While in Pakistan particularly one measure of micro-financing, assets, has noteworthy impact on access to financial services. In other words, overall impact of micro-financing on excess to finance is more significant in Bangladesh as compared to Pakistan. This result is supported by the facts as made known from survey conducted by IMF. As more suppliers exist in Bangladesh therefore more people have access to financial services in Bangladesh than Pakistan. The differences in impact between these countries exist due to several reasons i.e., differences in populace sizes, areas, density of population etc.

The remarkable impact of micro-financing on economic growth is found and also supported by literature (Trivedi, 2014; Azeem, Badar, \& Butt, 2014; Lacalle-Calderón, 2015; Raihan, 2015). The comparative results of Pakistan and Bangladesh show that more momentous influence exists in Pakistan than Bangladesh. The statistics and trend of economic growth 
(GDP) reflects that GDP of Pakistan is greater than Bangladesh. At present, Bangladesh's economy is on a steady path with an encouraging near-term macroeconomic attitude.

\section{Limitations and Future Directions}

This study fills up the gap and limitation exhumed by previously conducted studies. The following limitations still continue to exist:

- This study is limited to only two specific countries i.e. Bangladesh and Pakistan while the other researchers may take into account more than two countries or areas.

- This study considered only major impacts of micro-financing i.e., poverty alleviation, access to financial services and economic growth while many other impacts exist for future studies like growth of existing business, employment generation, women empowerment etc.

\section{References}

Ademolae, A., \& Arogundade, K. (2014). The Impact of Microfinance on Economic Growth in Nigeria. Journal of Emerging Trends in Economics and Management Sciences, 5(5), 397-405.

Ahlin, C., \& Jiang, N. (2008). Can micro-credit bring development?. Journal of Development Economics, 86, 1-21. https://doi.org/10.1016/j.jdeveco.2007.08.002

Ahlin, C., Lin, J., \& Maio, M. (2011). Where does microfinance flourish? Microfinance institution performance in macroeconomic context. Journal of Development Economics, 95(2), 105-120. https://doi.org/10.1016/j.jdeveco.2010.04.004

Ahmeti, F. (2014). Microfinance as a Tool for Economic Development in Transitional Countries: Experience from Kosovo. European Scientific Journal, 10(4), 269-287.

Alam, C. M., \& Miyagi, K. (2004). An approachable analysis of Micro Enterprises in Bangladesh (No. 8, pp. 77-96). Working Paper.

Angelucci, M., Karlan, D., \& Zinman, J. (2013). Win some lose some? Evidence from a randomized microcredit program placement experiment by Compartamos Banco. NBER Working Paper No. 19119, Cambridge, M.A. https://doi.org/10.3386/w19119

Attanasio, O., Augsburg, B., De Haas, R., Fitzsimons, E., \& Harmgart, H. (2011). Group lending or individual lending? Evidence from a randomized field experiment in Mongolia. Pub ref: MPRA Paper No. 35439. https://doi.org/10.1920/wp.ifs.2011.1120

Augsburg, B., Haas, R. D., Harmgart, H., \& Meghir, C. (2012). Microfinance, poverty and education. IFS working paper. https://doi.org/10.1920/wp.ifs.2012.1215

Ayuub, S. (2013). Impact of Microfinance on Poverty Alleviation: A Case Study of NRSP in Bahawalpur of Pakistan. International Journal of Academic Research in Accounting, Finance and Management Sciences, 3(1), 119-135. 
Azeem, A., Badar, T., \& Butt, I. (2014). Waves of Microfinance and its Influence on Economic Growth of Pakistan. International Journal Of Multidisciplinary Consortium, 1(1). [Online] Available: http://ijmc.rtmonline.in/vol1iss1/043010.pdf

Banerjee, A., Duflo, E., Glennerster, R., \& Kinnan, C. (2009). The miracle of microfinance? Evidence from a randomized evaluation. [Online] Available:

http://econ-www.mit.edu/files/4162

Barnes, C. (2001). Microfinance Program Clients and Impact: An Assessment of Zambuko Trust, Zimbabwe, Assessing the Impacts of Microenterprise Services. (AIMS) (Washington, DC: United States Agency for International Development).

Beck, T., Demirgüç-Kunt, A., \& Honohan, P. (2008). Finance for all?: Policies and pitfalls in expanding access. World Bank Policy Research Report, World Bank

Beck, T., Demirgüç-Kunt, A., \& Peria, M. (2007). Banking services for everyone? Barriers to bank access and use around the world. Policy Research Working Paper 4079, World Bank, Washington, DC. https://doi.org/10.1596/1813-9450-4079

Beck, T., \& Levine, R. (2004). Stock markets, banks, and growth: Panel evidence. Journal of Banking \& Finance, 28(3), 423-442. https://doi.org/10.1016/S0378-4266(02)00408-9

Befekadu, B. K. (2007). Outreach and Financial Performance Analysis of Microfinance Institutions in Ethiopia, National Bank of Ethiopia. In Economic Research and Monetary Policy Directorate, African economic Conference, Addis Ababa, Ethiopia.

Bernasek, A. (2003). Banking on social change: Grameen Bank lending to women. International Journal of Politics, Culture and Society, 16(3), 369-385.

https://doi.org/10.1023/A:1022304311671

Buera, F., Kaboski, J. P., \& Shin, Y. (2012). The Macroeconomics of Microfinance, NBER Working Paper No. 17905, Cambridge, M.A. https://doi.org/10.3386/w17905

Chowdhury, A. M. R., \& Bhuiya, A. (2001). Do Poverty Alleviation Programmes Reduce Inequity in Health: Lessons from Bangladesh. Quoted in Poverty Inequity and Health, eds. D. Leon and G. Walt. Oxford: Oxford University Press.

Chowdhury, M. J. A. (2004). Poverty and Microfinance in the Philippines. Bangladesh: University of Dhaka.

Coleman, B. E. (2004). Microfinance in Northeast Thailand: Who benefits and how much?. World Development Report.

Crépon, B., Duflo, E., Devoto, F., \& Pariente, W. (2011). Impact of microcredit in rural areas of Morocco: Evidence from a randomized evaluation. J-PAL working paper.

Duflo, E., Banerjee, A., Glennerster, R., \& Kinnan, C. G. (2013).The Miracle of Microfinance? Evidence from a Randomized Evaluation. NBER working paper No.18950, Cambridge, M.A. https://doi.org/10.3386/w18950 
Dunn, E. (2002). Research Strategy for the AIMS Core Impact Assessments (Washington, DC: Office of Microenterprise Development Global Bureau, United States Agency for International Development/ Management Systems International).

Goldberg, N. (2005). Measuring the Impact of Microfinance: Taking Stock of What We Know. Grameen Foundation USA Publication Series (Washington, DC: Grameen Foundation).

Haseen, F. (2006). Change in Food and Nutrient Consumption among the Ultra Poor: Is the CFPR/TUP Programme Making a Difference?. CFPR/TUP Working Paper Series No. 11 (Dhaka and Ottawa: BRAC Aga Khan Foundation Canada).

Helms, B. (2006). Access for all: building inclusive financial systems. Washington, DC, C-GAP. https://doi.org/10.1596/978-0-8213-6360-7

Hermes, N., \& Meesters, A. (2011). The performance of microfinance institutions: Do macro conditions matter? In B. Armendariz \& M. Labie (Eds.), The Handbook of Microfinance (pp. 173-201). World Scientific, Singapore. https://doi.org/10.1142/9789814295666_0009

Hossain, M. (1988). Credit for the Alleviation of Rural Poverty: The Grameen Bank in Bangladesh. (Washington, DC: International Food Policy Research Institute).

Imai, K. S., \& Azam, M. S. (2012). Does microfinance reduce poverty in Bangladesh? New evidence from household panel data. Journal of Development Studies, 48(5), 633-653. https://doi.org/10.1080/00220388.2012.661853

Imai, K. S., Arun, T., \& Annim, S. K. (2010) Microfinance and household poverty reduction: New evidence from India. World Development, 38(12), 1760-1774.

https://doi.org/10.1016/j.worlddev.2010.04.006

Imai, K. S., Gaiha, R., Thapa, G., \& Annim, S. K. (2012). Microfinance and Poverty-A Macro Perspective. World Development, 40(8), 1675-1689.

https://doi.org/10.1016/j.worlddev.2012.04.013

Khan, Z. (2010). The Microfinance Sector in Pakistan - Full Article - QFINANCE. Financepractitioner.com. [Online] Available:

http://www.financepractitioner.com/financing-best-practice/a-silent-revolution-not-to-be-silen ced-an-overview-of-the-microfinance-sector-and-its-impact-in-pakistan?full

Khandker, S. (1998). Fighting poverty with microcredit: Experience in Bangladesh. Oxford University Press.

Khandker, S. (2005) Microfinance and poverty - Evidence using panel data from Bangladesh. World Bank Economic Review, 19(2), 263-286. https://doi.org/10.1093/wber/lhi008

Khandker, S. R., \& Samad, H. (2013). Microfinance growth and poverty reduction in Bangladesh: What does the longitudinal data say?. World Bank Working Paper, p. 16.

King, R. G., \& Levine, R. (1993a). Finance and Growth: Schumpeter Might Be Right. The Quarterly Journal of Economics, 108(3), 717-737. https://doi.org/10.2307/2118406 
La Porta, R., Lopez-de-Silanes, F., Shleifer, A., \& Vishny, R. (1998). Law and finance. Journal of Political Economy, 106, 1113-1155. https://doi.org/10.1086/250042

Lacalle-Calderón, M., Alfonso-Gil, J., \& Rico-Garrido, S. (2015). Foreign Aid and Microfinance: A new policy proposal for financing development. Iberoamerican Journal of Development Studies, 4(2), 106-129. https://doi.org/10.26754/ojs_ried/ijds.145

Ledgerwood, J. (1998). The Micro finance Handbook: An Institutional and Financial Perspective. SBP Technical Paper Series, December.

https://doi.org/10.1596/978-0-8213-4306-7

Levine, R., \& Zervos, S. (1998). Stock markets, banks, and economic growth. American economic review, 537-558. https://doi.org/10.1596/1813-9450-1690

Littlefield, E., Murduch, J., \& Hashemi, S. (2003). Is microfinance an effective strategy to reach the millennium development goals? Washington, DC: World Bank.

Mahjabeen, R. (2008). Microfinancing in Bangladesh: Impact on households, consumption and welfare. Journal of Policy Modeling, 30, 1083-1092.

https://doi.org/10.1016/j.jpolmod.2007.12.007

McKernan, S. M. (2002). The impact of microfinance programs on self-employment profits: Do non-credit program aspects matter?. The Review of Economics and Statistics, 84(1), 93-115. https://doi.org/10.1162/003465302317331946

Miled, K. B. H., \& Rejeb, J. E. B. (2015). Microfinance and Poverty Reduction: A Review and Synthesis of Empirical Evidence. Procedia-Social and Behavioral Sciences, 195, 705-712. https://doi.org/10.1016/j.sbspro.2015.06.339

Miller, J., \& Martinez, R. (2006). Championship league: An overview of 80 leading Latin American providers of microfinance. [Online] Available:

http://www.themix.org/publications/microbanking-bulletin.

MkNelly, B., \& Dunford, C. (1998). Impact of credit with education on mothers and their young children's nutrition: Lower Pra Rural Bank credit with education program in Ghana. Freedom from Hunger Research Paper, 4, 1-5.

Mosley, P. (2001). Microfinance and poverty in Bolivia. Journal of Development Studies, 37(4), 101-132. https://doi.org/10.1080/00220380412331322061

Murdoch, J., \& Barbara, H. (2002). Analysis of the Effects of Microfinance on Poverty Reduction. NYU Wagner Working Paper No. 1014. [Online] Available:

http://www.nyu.edu/wagner/public_html/cgibin/ workingPapers/wp1014.pdf

Obasi, N. J., Chukwuka, O. I., \& Akwawa, U. A. (2014). Impact of Microfinance Lending On Economic Growth of Third world Nations: Study of Nigeria. International Journal of Business, Economics and Management, 1(8), 201-215.

Oikocredit (2005). Horizons. [Online] Available:

http://horizons.pcusa.org/archives/2005/hrznspot05/loans.htm 


\section{Macrothink}

Business and Economic Research ISSN 2162-4860 2020, Vol. 10, No. 3

Okurut, N., Schoombee, A., \& Berg, S. (2005). Credit demand and credit rationing in the informal financial sector in Uganda. South African Journal of Economics, 73(3), 482-497. https://doi.org/10.1111/j.1813-6982.2005.00033.x

Otero, M. (1999). Bringing development back, into microfinance. Journal of Microfinance/ESR Review, 1(1), 8-19.

Panjaitan-Drioadisuryo, R. D. M., \& Cloud, K. (1999). Gender, Self-Employment and Microcredit Programs: An Indonesian Case Study. The Quarterly Review of Economics and Finance, 39, 769-79. https://doi.org/10.1016/S1062-9769(99)00028-9

Paul, U. (2014). Microfinance Is an Anti-Poverty Tool for Rural Development: A Study. International Journal of Development Research, 4(4), 915-918.

Qureshi, M. I., Saleem, M. A., Khan, G. U., \& Ali, M. I. (2012). A Conceptual Framework: Role \& Impact Relationship between Micro Finance and Poor'S Access a case study of DIKhan District Khyber Pakhtunkhwa, Pakistan. Interdisciplinary Journal of Contemporary Research in Business, 3(10), 717-732.

Rabbani, M., Prakash, V. A., \& Sulaiman, M. (2006). Impact Assessment of CFPR/TUP: A Descriptive Analysis Based on 2002-2005 Panel Data, CFPR/TUP Working Paper Series No. 12, Dhaka and Ottawa: BRAC and Aga Khan Foundation Canada.

Raihan, S., Osmani, S. R., \& Khalily, M. B. (2015). Contribution of Microfinance to the Gross Domestic Product (GDP) of Bangladesh.

Rajan, R., \& Zingales, L. (1998). Financial Dependence and Growth. American Economic Review, 88(3), 559-86.

Rastogi, R. (2014). Microfinance: A Study of Asa Microfinance, Bangladesh and Bandhan Microfinance Institution of India. International Journal of Research in Management \& Social Science, 7.

Ravallion, M. (2001). Growth, inequality, and poverty: Looking beyond averages. World Development, 29(11), 23-49. https://doi.org/10.1016/S0305-750X(01)00072-9

Roodman, D. (2012). Due Diligence: An impertinent inquiry into microfinance. Washington D.C.: Center for Global Development.

Sachs, J. (2005). Investing in development: A practical plan to achieve the millennium development goals. London, UK: Earthscan.

Samer, S., Majid, I., Rizal, S., Muhamad, M. R., \& Rashid, N. (2015). The Impact of Microfinance on Poverty Reduction: Empirical Evidence from Malaysian Perspective. Procedia-Social and Behavioral Sciences, 195, 721-728.

https://doi.org/10.1016/j.sbspro.2015.06.343

Schumpeter, J. A. (1934). The theory of economic development: An inquiry into profits, capital, credit, interest, and the business cycle. Oxford: Oxford University Press. 


\section{Macrothink}

Business and Economic Research ISSN 2162-4860 2020, Vol. 10, No. 3

Shankar, S. (2013). Financial Inclusion in India: Do Microfinance Institutions Address Access Barriers. ACRN Journal of Entrepreneurship Perspectives, 2(1), 60-74.

Sichanthongthip, C. (2004). Loan repayment and impact on income in Lao microfinance: Saithani case. Doctoral dissertation, Master thesis, Sophia University, Tokyo.

Simanowitz, A. (2003). Appraising the Poverty Outreach of Microfinance: A Review of the CGAP Poverty Assessment Tool (PAT). Occasional Paper 1. Imp-Act, Institute of Development Studies.

Sivachithappa, K. (2013). Impact of Micro Finance on Income Generation and Livelihood of Members of Self Help Groups-A Case Study of Mandya District, India. Procedia - Social and Behavioral Sciences, 91, 228-240. https://doi.org/10.1016/j.sbspro.2013.08.421

Snodgrass, D. R., \& Sebstad, J. (2002). Clients in Context: The Impact of Microfinance in Three Countries-Synthesis Report. Washington, DC: Office of Microenterprise Development Global Bureau, United States Agency for International Development/Management Systems International.

Stephens, B., \& Tazi, H. (2006), Performance and transparency: A survey of microfinance in South Asia. [Online] Available: http://www.themix.org/publications/microbanking-bulletin

Trivedi, K. (2014). A Study on Relationship between Microfinance and Economic Development in India. Centre for Financial Services | Gujarat Technological University | CCFS2014. [Online] Available: http://gtuelibrary.edu.in/E-Book/Repository/CCFS/19.pdf

Weber, R., \& Musshoff, O. (2013). Can flexible microfinance loans improve credit access for farmers?. Agricultural Finance Review, 73(2), 255-271.

https://doi.org/10.1108/AFR-09-2012-0050

Woolley, J. T. (2008). Microfinance performance and domestic GDP growth: Testing the resiliency of microfinance institutions to economic change. Stanford Journal of Microfinance, $1(1)$.

World Bank. (2004). Brazil: Access to Financial Services. World Bank Report No. 27773-BR.

Zaman, H. (2000). Assessing the Poverty and Vulnerability Impact of Micro-Credit in Bangladesh: A Case Study of BRAC. Washington, D.C.: The World Bank.

Zulfiqar, G. M. (2013). Microfinance: A tool for financial access, poverty alleviation or gender empowerment?--Empirical findings from Pakistan. Doctoral dissertation, University of Massachusetts Boston. [Online] Available: http://gradworks.umi.com/3608538.pdf

\section{Copyright Disclaimer}

Copyright for this article is retained by the author(s), with first publication rights granted to the journal.

This is an open-access article distributed under the terms and conditions of the Creative Commons Attribution license (http://creativecommons.org/licenses/by/4.0/). 